\title{
36. COMPOSITION, K-Ar DATES AND ORIGIN OF A MID-EOCENE RHYOLITIC ASH LAYER AT DEEP SEA DRILLING PROJECT SITES 605 AND 613, NEW JERSEY TRANSECT, LEGS 93 AND 951
}

\author{
Ulrich von Rad and Hans Kreuzer, Bundesanstalt für Geowissenschaften und Rohstoffe, Hannover ${ }^{2}$
}

\begin{abstract}
A 2-5-cm-thick, middle to lower middle Eocene, vitreous ash layer of rhyolitic composition can be correlated between Sites 605 and 613 on the uppermost continental rise off New Jersey. The ash is tentatively interpreted as a windtransported submarine fallout tephra from a major subaerial eruption of the Bermuda volcano, shortly after its emergence above sea level. The $\mathrm{K}-\mathrm{Ar}$ dates of $45 \mathrm{Ma}$ for a coarse size fraction of the two ashes and $40 \mathrm{Ma}$ for a fine fraction of one of the samples are discordant and are only in rough agreement with the biostratigraphic age.
\end{abstract}

\section{INTRODUCTION}

Ash layers are very rare in the Cretaceous and Tertiary sediments of the eastern North American continental margin. Today, the volcanic centers of the Bermuda Islands to the southeast and of the Caribbean area to the south are about 1000 and $2000 \mathrm{~km}$ away (Fig. 1). To our knowledge, no distinct ash layers were reported from the Eocene sections of other DSDP sites between the New Jersey continental margin and Bermuda. (e.g., Sites $386,387,8,108,612$ ) or from the COST B-2 and COST B-3 wells, in which mid-Eocene sediments were also penetrated (Tucholke, 1979; Scholle, 1977, 1980). Therefore, the vitreous ash layer in Samples 605-21-2, $145-147 \mathrm{~cm}$ and $613-34-1,104-109 \mathrm{~cm}$, from two sites which are located only $8 \mathrm{~km}$ apart on the uppermost continental rise off New Jersey, form an important marker horizon which interrupts the monotonous, hemipelagic, calcareous sedimentation. This ash layer helps to correlate both sites, calibrates the biostratigraphic age data, and allows us to draw some inferences about the structural and volcanic evolution of the distant Bermuda archipelago.

\section{METHODS}

We investigated the composition and texture of the ash layers by smear slides (Table 1), grain mounts, and thin sections (Fig. 2). The samples were sieved into subsamples of $<32$ and $>32(32-250) \mu \mathrm{m}$; however, the $<32 \mu \mathrm{m}$ fraction of the Site 605 sample was too small for analyses. For the isotope and chemical analyses the vitreous glass was concentrated by decalcification (formic acid) and for the Site 605 sample, in addition, by heavy liquids to separate pyrite (and glauconite) from the lighter-weight glass. The two size fractions of the Site 613 sample were analyzed for major and trace elements by X-ray fluorescence (XRF) (see Table 2). Conventional total-fusion, mass-spectrometric, isotope-dilution argon analyses and flame-photometric potassium analyses were performed on the single size fraction of the Site 605 sample and the two size fractions of the Site 613 sample (Table 3). Brief analytical details are given by Seidel et al. (1982), and results

\footnotetext{
${ }^{1}$ van Hinte, J. E., Wise, S. W., Jr., et al., Init. Repts. DSDP, 93: Washington (U.S. Govt, Printing Office).

2 Addresses: Bundesanstalt für Geowissenschaften und Rohstoffe, Postfach 510153, D-3000 Hannover 51, Federal Republic of Germany.
}

for standard minerals are in the interlaboratory compilation of Odin (1982a).

\section{PETROGRAPHY AND GEOCHEMISTRY}

The ash layer at Site 605 is $2-3 \mathrm{~cm}$ thick; the layer at Site 613 is $5 \mathrm{~cm}$ thick. Petrographically, both layers are similar, and their volcanic constituents appear to be identical. The layers consist mostly of comparatively fresh, transparent, light-colored, highly vesicular pumice fragments and about $30 \%$ bubble-wall shards, mostly less than $40 \mu \mathrm{m}$ in diameter (Fig. 2; Table 1) with a maximum size of $150 \mu \mathrm{m}$. Their refractive index is $\mathrm{n}=1.495-1.500$. The ash layer at Site 605 contains much secondary pyrite, some quartz, feldspar, "clay"/leucoxene aggregates (probably altered glass), biogenic carbonate, and traces of glauconite. The ash layer at Site 613 contains only very little quartz, feldspar, pyrite, biotite, "clay" aggregates, and no carbonate.

A high concentration of $\sim 99 \%$ glass was achieved in the $<32 \mu \mathrm{m}$ fraction of the ash from Site 613. For this fraction, as well as for the $>32 \mu \mathrm{m}$ fraction, which is less representative for the glass alone, the calculation of the volcanic norm (Müller, 1982) from the chemical composition (Table 2) points to a rhyolitic volcanic source. Compared with this composition, the refractive index of 1.495 to 1.500 seems to be reduced and is representative for (rhyolite to) pitchstone (Tröger, 1971; Huber and Rinehart, 1966), well in agreement with the patchy birefringence and the high loss on ignition (LOI) of 9.9 and $13.0 \mathrm{wt} . \%$, respectively (three to ten times higher than for unaltered glass) that these samples display.

\section{DISCUSSION OF K-Ar DATES}

The $\mathrm{K}-\mathrm{Ar}$ dates determined for the $>32 \mu \mathrm{m}$ fractions of both ash layers are the same: $44.5 \pm 1.2 \mathrm{Ma}$ for Site 605 , and $44.8 \pm 0.9 \mathrm{Ma}$ for Site 613. In contrast, the $\mathrm{K}-\mathrm{Ar}$ date determined for the $<32 \mu \mathrm{m}$ fraction of the ash layer from Site 613 is significantly younger, 39.9 $\pm 0.7 \mathrm{Ma}$ (Table 3 ). In this chapter we offer only tentative interpretations of these data.

We suggest that the ash layer represents an airborne ash from a subaerial oceanic environment. If this is so, 


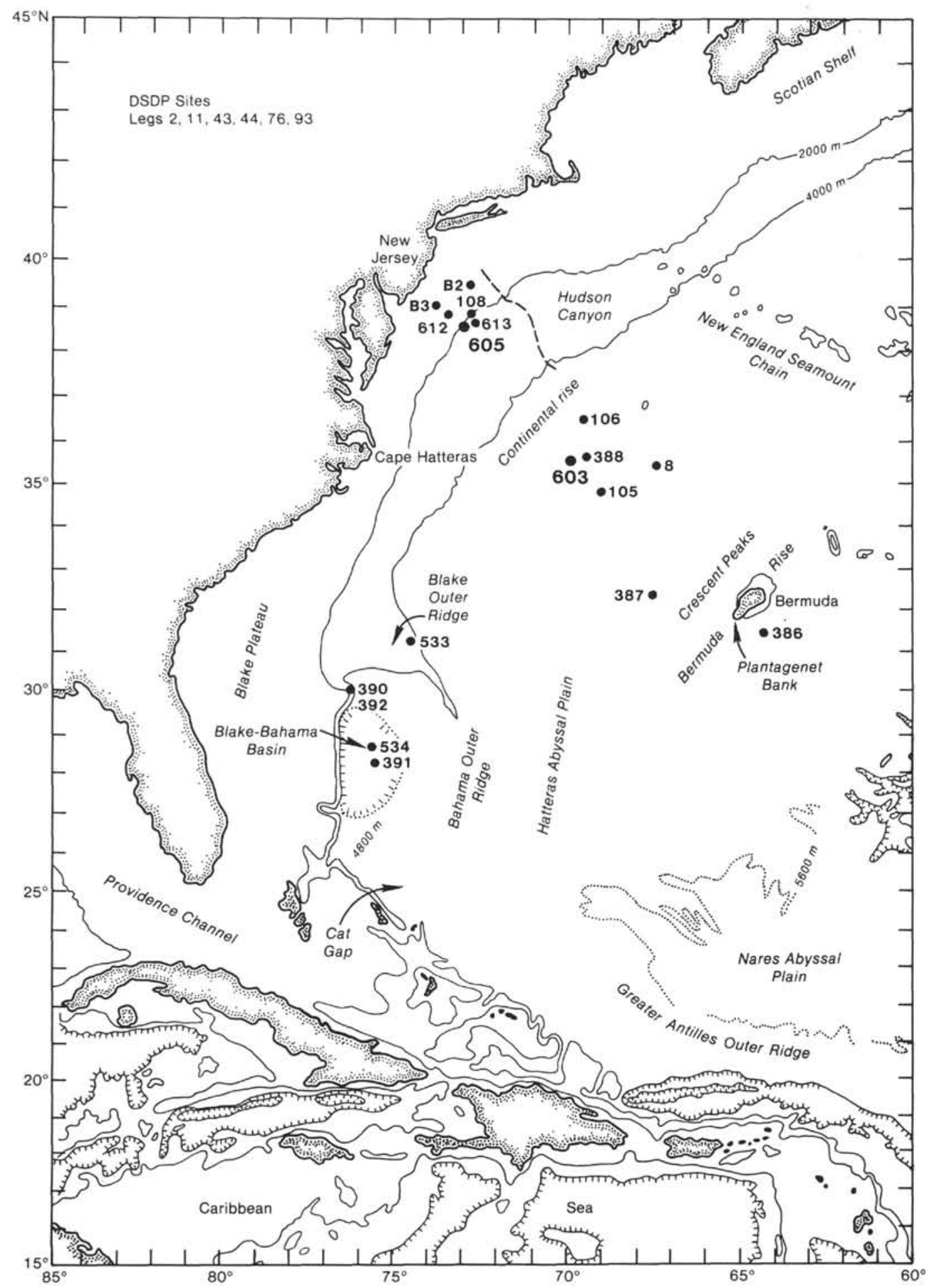

Figure 1. Location map of DSDP sites and of COST-B wells in the eastern North American Basin, and location of the potential source areas of the ash (Bermuda Islands, Caribbean).

the dates are not likely to be significantly too old from excess argon. Nor does an inherited component seem to be a problem, because the $>32 \mu \mathrm{m}$ fraction of the Site 613 sample, although contaminated with a trace of biotite, yielded the same date as the same fraction of the biotite-free Site 605 sample. However, the high LOI and the patchy birefringence of the glass show that it is al- tered. In general, any visible alteration of glass is accompanied by loss of radiogenic argon, leading to $\mathrm{K}-\mathrm{Ar}$ dates that are too young. From these arguments, we suggest that the three dates are minimum estimates of the age of eruption of the ashes and explain the significantly younger date by a large loss of radiogenic argon in the fine size fraction. 
Table 1. Geographic, biostratigraphic, and petrographic data for the ash layers.

\begin{tabular}{|c|c|c|}
\hline & $605-21-2,145-147 \mathrm{~cm}$ & $613-34-1,104-106 \mathrm{~cm}$ \\
\hline Coordinates & $38^{\circ} 44.5^{\prime} \mathrm{N}, 72^{\circ} 36.6^{\prime} \mathrm{W}$ & $38^{\circ} 46.3^{\prime} \mathrm{N}, 72^{\circ} 1.4^{\prime} \mathrm{W}$ \\
\hline Water depth (m) & 2194 & 2309 \\
\hline Depth in hole (m) & 340 & 403 \\
\hline Nannoplankton Zone & CP13 & CP13a \\
\hline Petrography & $\begin{array}{l}\text { Vitreous siliceous ash } \\
\text { layer, rhyolitic, } \\
2-3 \mathrm{~cm} \text { thick }\end{array}$ & $\begin{array}{l}\text { Vitreous siliceous ash } \\
\text { layer, rhyolitic, } \\
5 \mathrm{~cm} \text { thick }\end{array}$ \\
\hline \multicolumn{3}{|l|}{$\begin{array}{l}\text { Mineral composition } \\
\text { of the entire ash }\end{array}$} \\
\hline Size fraction $>32 \mu \mathrm{m}$ & $\begin{array}{l}\text { Glass, mod. altered, } \\
\text { much pyrite, } \\
\text { subord. qtz/ } \\
\text { feldspar, "clay" } \\
\text { aggr., carb., trace } \\
\text { of glauconite }\end{array}$ & $\begin{array}{l}\text { Glass, slightly altered, } \\
\text { qtz, feldspar, } \\
\text { pyrite, biotite, } \\
\text { "clay" aggr., } \\
\text { radiolarians }\end{array}$ \\
\hline Size fraction $<32 \mu \mathrm{m}$ & Not determined & $\begin{array}{l}\text { About } 99 \% \text { glass, } \\
\text { traces of pyrite, } \\
\text { biotite, qtz/feld- } \\
\text { spar, siliceous org., } \\
\text { "clay" aggregates }\end{array}$ \\
\hline $\begin{array}{l}\text { Refractive index } \\
\text { of glass }\end{array}$ & 1.495 to 1.500 & 1.495 to 1.500 \\
\hline
\end{tabular}

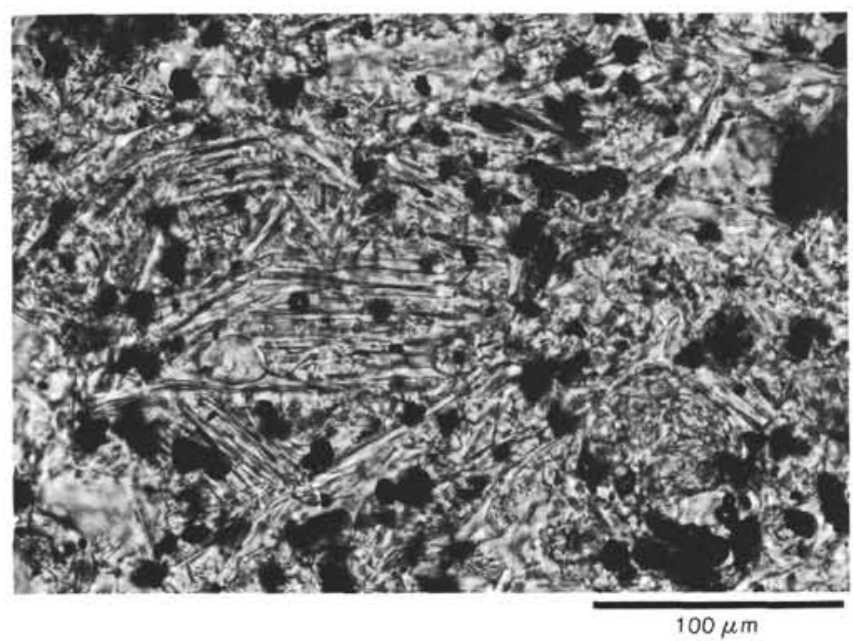

Figure 2. Vitreous ash layer with transparent bubble-wall glass shards, small pyrite spherules, and a few scattered, terrigenous quartz grains. Sample 605-21-2, 145-147 cm.

Biostratigraphic information from foraminifers, radiolarians, and nannofossils from the overlying and underlying silica-rich nannofossil chalk dates the ash layers at Sites 605 and 613 as nannoplankton Subzone CP13a (Poag, Watts, et al., in press). According to the correlation table of Bukry (1981, fig. 2), dates correspond to the early to the middle part of the middle Eocene (calcareous nannoplankton Zone NP15/lower part of NP16) and the early part of the middle Eocene (basal nannoplankton Zone NP15/NP16), respectively (Fig. 3).

In contrast, the timescales of Curry and Odin (1982) and Odin (1982b) suggest that basal NP15/NP16 correlates with a middle middle Eocene age of around 42 to $41 \mathrm{Ma}$. By this time scale, our "minimum age" of 45 Ma for the basal NP15/NP16 of the ash layer at Sites 605 and 613 seems to be too old. Either our assumptions about the origin of the ash are incorrect, or the dates are in accordance with the competing time scales
Table 2. X-ray fluorescence analyses ${ }^{a}$ of the two size fractions from the ash layer in Sample 613-34-2, $104-106 \mathrm{~cm}$.

\begin{tabular}{|c|c|c|}
\hline \multirow[b]{2}{*}{ Elements } & \multicolumn{2}{|c|}{ Fraction } \\
\hline & $>32 \mu \mathrm{m}$ & $<32 \mu \mathrm{m}$ \\
\hline \multicolumn{3}{|c|}{ Major elements (wt.\%) } \\
\hline $\mathrm{SiO}_{2}$ & 52.4 & 62.4 \\
\hline $\mathrm{TiO}_{2}$ & 0.2 & 0.3 \\
\hline $\mathrm{Al}_{2} \mathrm{O}_{3}$ & 10.5 & 12.7 \\
\hline $\mathrm{Fe}_{2} \mathrm{O}_{3}$ & 15.5 & 6.2 \\
\hline $\mathrm{MnO}^{\circ}$ & 0.03 & 0.03 \\
\hline $\mathrm{MgO}$ & 0.4 & 0.7 \\
\hline $\mathrm{CaO}$ & 1.8 & 1.2 \\
\hline $\mathrm{Na}_{2} \mathrm{O}$ & 2.1 & 2.6 \\
\hline $\mathrm{K}_{2} \mathrm{O}$ & 2.9 & 3.3 \\
\hline $\mathrm{P}_{2} \mathrm{O}_{5}$ & 0.06 & 0.1 \\
\hline $\mathrm{SO}_{3}$ & 0.7 & 0.1 \\
\hline LOÎ̉ & 13.0 & 9.9 \\
\hline Total & 99.6 & 99.5 \\
\hline
\end{tabular}

Trace element (ppm)

\begin{tabular}{|c|c|c|}
\hline $\mathrm{Ba}$ & 401 & 549 \\
\hline $\mathrm{Ce}$ & 11 & 49 \\
\hline Co & 17 & 10 \\
\hline $\mathrm{Cr}$ & 4 & 9 \\
\hline $\mathrm{La}$ & 3 & 33 \\
\hline $\mathrm{Sc}$ & 4 & 1 \\
\hline $\mathrm{v}$ & 11 & 15 \\
\hline As & $<5$ & $<5$ \\
\hline $\mathrm{Bi}$ & $<6$ & $<6$ \\
\hline $\mathrm{Cu}$ & 76 & 76 \\
\hline Mo & $<3$ & $<3$ \\
\hline $\mathrm{Nb}$ & 8 & 11 \\
\hline $\mathrm{Ni}$ & 32 & 54 \\
\hline $\mathrm{Pb}$ & 96 & 69 \\
\hline $\mathrm{Rb}$ & 74 & 82 \\
\hline Sn & 72 & 27 \\
\hline $\mathrm{Sr}$ & 212 & 233 \\
\hline Ta & 16 & 7 \\
\hline Th & 47 & 24 \\
\hline $\mathrm{U}$ & $<3$ & 4 \\
\hline w & 15 & 6 \\
\hline Y & $<3$ & $<3$ \\
\hline $\mathrm{Zn}$ & 68 & 33 \\
\hline $\mathrm{Zr}$ & 153 & 123 \\
\hline Total (wt.\%) & 0.1 & 0.1 \\
\hline \multicolumn{3}{|c|}{$\begin{array}{l}\text { Philipps XRF sequence spectrometers } \\
\text { PW } 1450 \text { (major elements) and PW } \\
1400 \text { (trace elements); matrix correction } \\
\text { by interelement Philips alpha-correction } \\
\text { factors; air-dry sample material; LOI at } \\
1000^{\circ} \mathrm{C} \text { in air; remainder mixed } 1: 5 \text { with } \\
1: 1 \text { mixture of } \mathrm{Li} \text { metaborate/tetrabora- } \\
\text { te and fused at } 1300^{\circ} \mathrm{C} \text { in a platinum } \\
\text { crucible. Analysts: } \mathrm{J} \text {. Lodziak and D. } \\
\text { Requard. }\end{array}$} \\
\hline
\end{tabular}

of other authors who regard glauconite dates as minimum estimates of the age of the host sediments, and who used dates of glauconites which Odin considers to be reworked (e.g., Hardenbol and Berggren, 1978). According to these last, the age of basal NP15/16 would be about 49 to $47 \mathrm{Ma}$ (recalculated, see Fig. 3).

\section{ORIGIN OF THE ASH LAYER}

Volcaniclastic turbidites and ash layers in marine sediments not only provide valuable, widespread stratigraphic markers (Kennett, 1981), but also permit the assessment of the tectonic and volcanic evolution of a volcanic 
Table 3. K-Ar data ${ }^{\mathrm{a}}$ for the ash layer at Site 605 (Leg 93) and 613 (Leg 95).

\begin{tabular}{|c|c|c|c|c|}
\hline \multirow{2}{*}{$\begin{array}{l}\text { Size fraction, } \\
\text { pretreatments, } \\
\text { composition }\end{array}$} & \multirow[b]{2}{*}{$\underset{\text { (wt.\%) }}{K}$} & \multicolumn{2}{|c|}{ Argon } & \multirow{2}{*}{$\begin{array}{l}\text { K-Ar } \\
\text { date } \\
\text { (Ma) }\end{array}$} \\
\hline & & $\begin{array}{l}\text { Atmospheric } \\
(\mathrm{n} 1 / \mathrm{g}) \text { STP }\end{array}$ & $\begin{array}{l}\text { Radiogenic } \\
\text { (nl/g) STPP }\end{array}$ & \\
\hline \multicolumn{5}{|l|}{ Sample $605-21-2,145-147 \mathrm{~cm}$} \\
\hline $\begin{array}{l}32-250 \mu \mathrm{m} \text {, formic acid, partly } \\
15 \% \mathrm{HCl} \text {, density }<2.8 \\
\mathrm{~g} / \mathrm{cm}^{3} \text { predomin. mod. } \\
\text { altered glass, subord. fresh } \\
\text { glass, qtz/feldspar, "clay" } \\
\text { aggr., trace of ore }\end{array}$ & $\begin{array}{l}2.87 \\
\frac{2.84}{\text { Mean }} \\
2.85 \\
\pm 0.04\end{array}$ & $\begin{array}{r}4.23 \\
\pm 0.43\end{array}$ & $\begin{array}{r}4.99 \\
\pm 0.12\end{array}$ & $\begin{array}{r}44.5 \\
\pm 1.2\end{array}$ \\
\hline \multicolumn{5}{|l|}{ Sample 613-34-1, 104-106 cm } \\
\hline $\begin{array}{l}>32 \mu \mathrm{m}, 90 \% \text { glass, } 7 \% \\
\text { aggregates, } 2 \% \text { pyrite, } 1 \% \\
\text { biotite } \\
<32 \mu \mathrm{m}, 99 \% \text { glass, traces of } \\
\text { pyrite, biotite, quartz, } \\
\text { feldspar, and "clay" aggr. }\end{array}$ & $\begin{array}{c}2.37 \\
\text { Mean } \frac{2.39}{2.38} \text { XRF } \\
\pm 0.04 \\
2.69 \\
2.70 \text { XRF } \\
\text { Mean } \overline{2.70} \\
\pm 0.04\end{array}$ & $\begin{array}{r}7.28 \\
7.70 \\
7.5 \\
\pm 0.4 \\
11.2 \\
10.6 \\
10.9 \\
\pm 0.7\end{array}$ & $\begin{array}{r}4.18 \\
4.21 \\
4.19 \\
\pm 0.04 \\
4.24 \\
4.23 \\
4.23 \\
\pm 0.04\end{array}$ & $\begin{array}{r}44.8 \\
\pm 0.9\end{array}$ \\
\hline $\begin{array}{l}\text { a Argon in nanoliters per gram at } \\
\text { the mean of blank analyses. IUGS } \\
\text { rors estimated at the level of } 95 \% \\
\text { standard minerals are } 1 \% \text { younge } \\
\text { (Odin, 1982a). }\end{array}$ & $\begin{array}{l}\text { ecommended cons } \\
\text { intralaboratory an } \\
\text { than the mean va }\end{array}$ & $\begin{array}{l}\text { tical confide } \\
s \text { of an inte }\end{array}$ & $\begin{array}{l}\text { g) STP, corr } \\
\text { and Jäger, } \\
\text { c. Our K-A } \\
\text { boratory co }\end{array}$ & $\begin{array}{l}\text { ted for } \\
\text { 7). Er- } \\
\text { ates of } \\
\text { arison }\end{array}$ \\
\hline
\end{tabular}

archipelago from its submarine seamount to subaerial volcano stage (Schmincke and von Rad, 1979; Fisher and Schmincke, 1984).

Since no volcanic province lies close to Sites 605 and 613 , we have to look for more distant source areas. Tentatively, we suggest that the ash layers were derived from a major, explosive, subaerial eruption of the midplate volcanic edifice of Bermuda Island. Site $386,90 \mathrm{~km}$ southeast of Bermuda (Fig. 1), penetrated the entire volcanogenic formation (Vogt and Tucholke, 1979). Volcaniclastic, clinopyroxene-rich turbidites recording the subaerial weathering of Bermuda appear in the upper middle to lower upper Eocene and continue through the upper Oligocene; volcaniclastic debris and scattered ash occur up to the middle Miocene (Galehouse, 1979). The thickest volcaniclastic turbidites were found in Core 38613 (NP17/18, about 38 to $36 \mathrm{Ma}$ or 42 to $39 \mathrm{Ma}$, depending on the preferred timescale, see Fig. 3). This suggests that about 50-70 Ma after the formation of the surrounding seafloor at the Bermuda Pedestal "the principal Bermuda volcanoes had been constructed to and above sea level in a main shield-building tholeiitic stage at about 46 Ma B.P. (recalculated according to Steiger and Jäger, 1977)" and that "the volcanoes were largely levelled by erosion in the next 10-20 Ma". Furthermore, "during the erosional period, some ash-producing volcanism may have occurred" (Vogt and Tucholke, 1979, p. 854; Reynolds and Aumento, 1974). Discrete ash layers, recording ash-producing volcanism during the postearly Eocene erosional phase, are absent at DSDP Site 386 on the Bermuda Pedestal and at Site 387 on the Bermuda Rise (Fig. 1). This is surprising in view of the ash layer at Sites 605 and 613 , which were at that time about $600 \mathrm{~km}$ northwest of Bermuda. Maybe southeasterly highaltitude winds dispersed the fine-grained vesicular ash shards only to the northwest, where the pumice fell into the sea. However, another possibility which cannot be
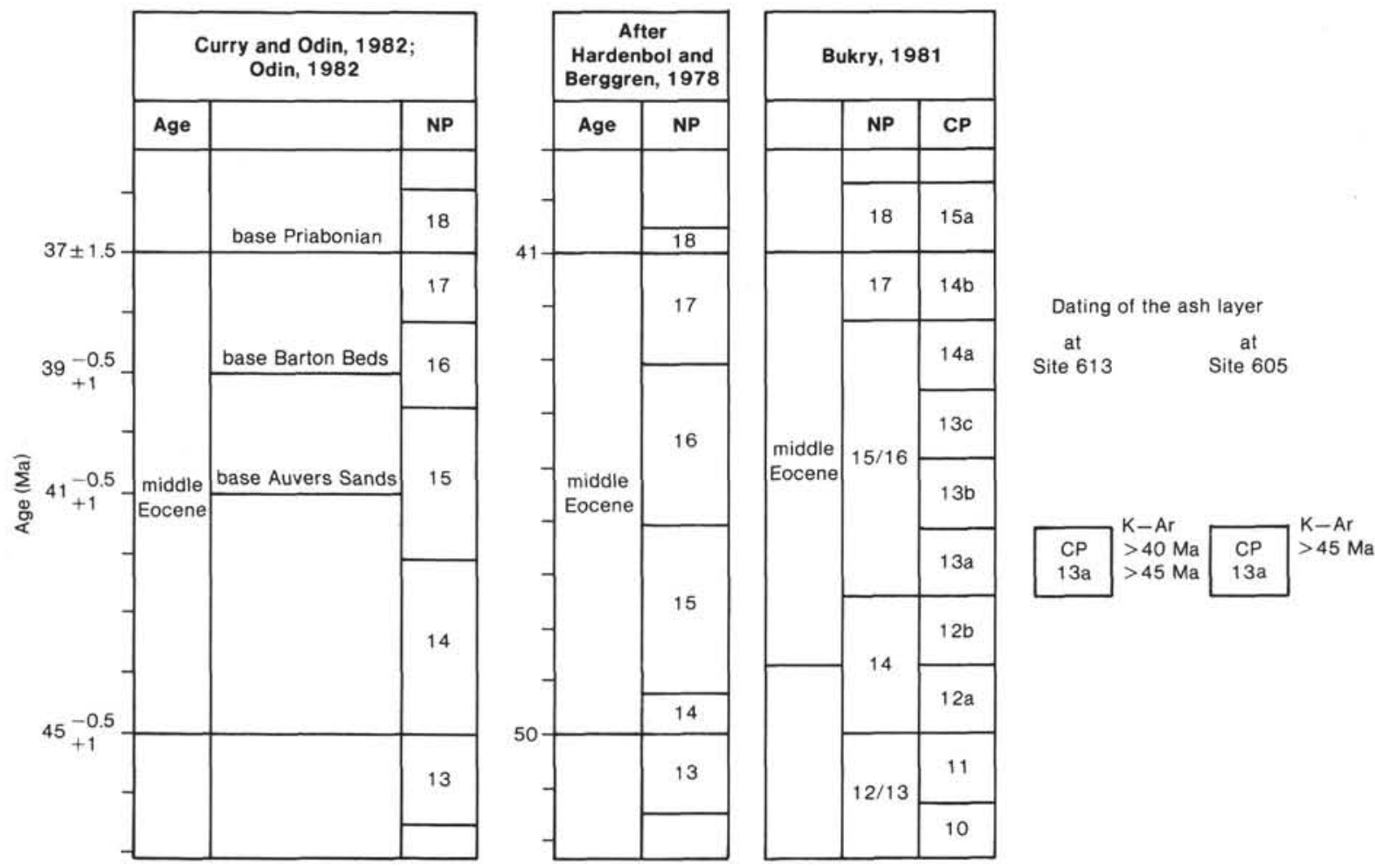

Figure 3. Comparison of different timescales with the age estimates for the ash layers. NP and CP are zonations of calcareous nannoplankton. Arbitrarily, we adjusted the bases of NP18 and NP14 to the same levels. The timescale of Hardenbol and Berggren is increased by $1 \mathrm{Ma}$ to account for the change due to the constants recommended by the International Union of Geological Scientists (Steiger and Jäger, 1977). 
ruled out would suggest that the ash layers originated from Caribbean volcanic centers, now $>2000 \mathrm{~km}$ to the south, which were highly active during the middle Eocene.

\section{ACKNOWLEDGMENTS}

We are grateful to G. Mountain and C. Schreiber for providing the Site 613 ash, to H. Raschka for the XRF analyses, and to H. Klappert, M. Metz, and L. Thiesswald for assisting in the $\mathrm{K}-\mathrm{Ar}$ analyses. $\mathrm{K}$. Burgath and M. Mohr discussed the alteration. P. Müller calculated volcanite norms to classify the volcanism. J. Aronson, D. A. Dunn, and G. S. Russell critically read the manuscript and made many helpful suggestions to improve its content.

\section{REFERENCES}

Bukry, D., 1981. Cenozoic coccoliths from the Deep Sea Drilling Project. In Warme, J. E., Douglas, R. G., and Winterer, E. L. (Eds.), The Deep Sea Drilling Project: A Decade of Progress. Soc. Econ. Paleont. Mineral, Spec. Publ., 32:335-353.

Curry, D., and Odin, G. S., 1982. Dating of the Paleogene. In Odin, G. S. (Ed.), Numerical Dating in Stratigraphy: New York (Wiley), pp. 607-630.

Fisher, R. V., and Schmincke, H. U., 1984. Pyroclastic Rocks: Berlin (Springer).

Galehouse, J. S., 1979. Heavy mineralogy and provenance of volcaniclastic turbidites of Site 386. In Tucholke, B. E., Vogt, P. R., et al., Init. Repts. DSDP, 43: Washington (U.S. Govt. Printing Office), 407-409.

Hardenbol, J., and Berggren, W. A., 1978. A new Paleogene time scale. In Cohee, G. V., Glaessner, M. F., and Hedberg, H. D. (Eds.), Contributions to the Geologic Time Scale. Am. Assoc. Pet. Geol. Stud. Geol., 6:213-234.

Huber, N. K., and Rinehart, D. D., 1966. Some relationships between the refractive index of fused glass beads and the petrologic affinity of volcanic rock suites. Geol. Soc. Bull., 77:101-110.

Kennett, J. R., 1981. Marine tephrochronology. In Emiliani, C. (Ed.), The Oceanic Lithosphere: The Sea (Vol. 7): New York (Wiley-Interscience), 1373-1436.

Müller, P., 1982. Von der CIPW-Norm ausgehende Berechnung von Mineralbeständen magmatischer Gesteine in Analogie zu der ModalZusammensetzung plutonischer und vulkanischer Gesteine. Geol. Jb., D 55.
Odin, G. S., 1982a. Interlaboratory standard minerals for dating purposes. In Odin, G. S. (Ed.), Numerical Dating in Stratigraphy: New York (Wiley), pp. 123-150.

Poag, C. W., Watts, A. B., et al., in press. Site 613. In Poag, C. W., Watts, A. B., et al., Init. Repts. DSDP, 95: Washington (U.S. Govt. Printing Office).

Reynolds, P. H., and Aumento, F., 1974. Deep Drill 1972. Potassiumargon dating of the Bermuda drill core. Can. J. Earth Sci., 11: 1269-1273.

Schmincke, H. U., and von Rad, U., 1979. Neogene evolution of Canary Island volcanism inferred from ash layers and volcaniclastic sandstones of DSDP Site 397 (Leg 47A). In von Rad, U., Ryan, W. B. F., et al., Init. Repts. DSDP, 47, Pt. 1: Washington (U.S. Govt. Printing Office), 703-725.

Scholle, P. A. (Ed.), 1977. Geological Studies on the COST No. B-2 Well, U.S. Mid-Atlantic Outer Continental Shelf Area. U.S. Geol. Surv. Circular 750.

(Ed.), 1980. Geological Studies on the COST No. B-3 well, U.S. Mid-Atlantic Continental Slope Area U.S. Geol. Surv. Circular 833.

Seidel, E., Kreuzer, H., and Harre, W., 1982. A late Oligocene/early Miocene high pressure belt in the external Hellenides. Geol. Jb., E 23:165-206.

Steiger, R. H., and Jäger, E., 1977. Subcommission on Geochronology: convention on the use of decay constants in geo- and cosmochronology. Earth Planet. Sci. Lett., 36:359-362.

Tröger, W. E., 1971. Optische Bestimmung der geseinsbildenden Minerale, Teil 1 Bestimmungstabellen (4th revised ed. by Bambauer, H. U., Taborszky, F., and Trochim, H. D.): Stuttgart (Schweizerbart)

Tucholke, B. E., 1979. Relationships between acoustic stratigraphy and lithostratigraphy in the western North Atlantic Basin. In Tucholke, B. E., Vogt, P. R., et al., Init. Repts. DSDP, 43: Washington (U.S. Govt. Printing Office), 827-846.

Vogt, P. R., and Tucholke, B. E., 1979. The New England seamounts: testing origins. In Tucholke, B. E., Vogt, P. R., et al., Init. Repts. $D S D P, 43$ : Washington (U.S. Govt. Printing Office), 847-856.

Date of Initial Receipt: 24 January 1985

Date of Acceptance: 21 October 1985 